Dr. sc. Alena JURIĆ, izvanredna profesorica

Pravni fakultet Sveučilišta u Mostaru

alena.juric@pf.sum.ba

Mr. sc. Davor MILARDOVIĆ,

doktorand Pravnog fakulteta Sveučilišsta u Mostaru

dmilardovic5@gmail.com

\title{
ZAHTJEV VLASTORUČNOSTI HOLOGRAFSKE OPORUKE
}

Sažetak: Holografsku oporuku poznaju najpoznatije svjetske kodifikacije građanskog prava. Najvažnije prednosti holografske oporuke su: potpuna tajnost sadržaja, mogućnost njenog sastavljanja u bilo koje doba, na jednostavan način, uz minimalne troškove. Njeni nedostaci su: podložnost krivotvorenju, ponekad nerazumljivost određenih riječi ili rečenica, nesigurnost oporuke ako ostane na čuvanju kod ostavitelja. Svaka oporuka pa tako i holografska oporuka je strogo formalni pravni posao, u kojem je oblik jedna od pretpostavki njegove valjanosti. Temeljni uvjet pravne valjanosti holografske oporuke jest zahtjev vlastoručnosti pri njenom sastavljanju, odnosno vlastoručnost u pisanju i potpisivanju oporuke. U radu se istražuju granice zahtjeva vlastoručnosti, u smislu njihovog pravnog i praktičnog značaja. Analizira se normativno određenje oporuke, pravni učinci holografske oporuke koju je napisao oporučitelj s tjelesnim poteškoćama koristeći pritom vanjsku pomoć, pravni učinci stenografskog sastavljanja holografske oporuke, pitanje sadržaja pojma "vlastoručnost potpisivanja", pravni učinci potpisivanja oporuke sastavljene u vidu deklaracije, potpisivanje oporuke napisane na više listova i sl. U radu se konsultira komparativno pravo, kao i relevantna sudska praksa. U pogledu prijepornih pitanja, odnosno neujednačenosti stavova pravne znanosti, iznose se prijedlozi de lege ferenda.

Ključne riječi: slobodna volja, holografska oporuka, pravovaljanost oporuke, rukopis, stenografija, potpis oporučitelja, tjelesne poteškoće oporučitelja, oporuka u vidu deklaracije.

\section{Uvod}

Holografska ili vlastoručna oporuka (na lat. testamentum holographum; engl. holographic will; njem. eigenhändiges Testament, holographisches Testament; franc. testament olographe) je oblik privatne, redovite oporuke koja se može sastaviti bilo kada bez obzira na okolnosti. ${ }^{1}$ Holografsku oporuku poznaju najve-

PEZO, V. (gl. ur.), Odrednica: Vlastoručna oporuka, Pravni leksikon, Leksikografski zavod Miroslav Krleža, Zagreb, 2007., str. 1767.; Holografska oporuka, testamentum holo- 
će kodifikacije građanskog prava u svijetu kao jedan od općeprihvaćenih oblika oporučivanja. Sve oporuke pa tako i holografska oporuka imaju solemnitetni karakter, tako da bilo koje pa i najmanje odstupanje od propisanog oblika može imati za posljedicu ništavost oporuke. ${ }^{2}$ Poništenje oporuke zbog nedostatka oblika, poslije otvaranja naslijeđa, može tražiti samo osoba koja ima pravni interes, i to u roku od jedne godine od kada je saznala za oporuku, a najduže u roku od deset godina od proglašenja oporuke. ${ }^{3}$

Suvremena pravna znanost holografsku oporuku određuje kao redovitu oporuku jer se sačinjava u svim prilikama, bez obzira na činjenicu u kojim se okolnostima našao oporučitelj te kao pisanu oporuku jer se sačinjava u pisanom obliku. ${ }^{4}$ Radi se i o privatnoj oporuci s obzirom na to da u procesu njenog sačinjavanja ne sudjeluje tijelo javne vlasti, kao ni osoba koja ima javne ovlasti. ${ }^{5}$ Osim povijesnog osvrta na holografsku oporuku, u radu se analiziraju normativno određenje oporuke, granice vlastoručnog pisanja oporuke, pravni učinci holografske oporuke koju je napisao oporučitelj s tjelesnim poteškoćama koristeći pritom vanjsku pomoć, pravni učinci stenografskog sastavljanja holografske oporuke, pitanje sadržaja pojma "vlastoručnost potpisivanja", pravni učinci potpisivanja oporuke sačinjene u vidu deklaracije, potpisivanje oporuke napisane na više listova i sl.

\section{Povijesni osvrt na vlastoručnu oporuku}

Rimsko pravo je poznavalo holografsku oporuku. Međutim, tu oporuku u rimskom pravu ostavitelj je trebao vlastoručno napisati, ali ne i potpisati. Nije ju bilo potrebno potpisati ako je u njoj bilo istaknuto da ju je napisao sam ostavitelj. ${ }^{6}$

graphum, potječe od latinskog termina testamentum, testament, oporuka, i grčkih termina holographus, holos, odnosno sav, potpun, cijeli, kao i grafein, odnosno pisati, napisati. V. ĆERANIĆ, D., Svojeručni testament, Anali Pravnog fakulteta Univerziteta u Zenici, god. 3., br. 5., Zenica, 2010., str. 36.; SVORCAN, S. N., Nasledno pravo, Pravni fakultet u Kragujevcu, Kragujevac, 2006., str. 49.

2 BELAJ, V., Oblik oporuke prema Zakonu o nasljeđivanju, Pravni vjesnik, god. 20, br. 1-2, Osijek, 2004., str. 12., dostupno na: https://www.pravos.unios.hr/pfo/sites/default/files/ Vjesnik-pdf/Izdanja/Pravni-vjesnik-2004-1-2.pdf (1. 9. 2021.).

V. čl. 65. Zakona o nasljeđivanju Federacije Bosne i Hercegovine, Službene novine FBiH, br. 80/14. i 32/19. (dalje u tekstu: ZN FBiH); čl. 67. Zakona o nasljeđivanju Republike Srpske, Službeni glasnik RS, br. 1/09., 55/09., 91/16., 28/19. i 82/19. (dalje u tekstu: ZN RS); čl. 68. Zakon o nasljeđivanju Brčko distrikta Bosne i Hercegovine, Službeni glasnik Brčko distrikta $\mathrm{BiH}$, br. 36/17. (dalje u tekstu: $\mathrm{ZN} \mathrm{BD} \mathrm{BiH).}$

$4 \quad$ MOMČILOVIĆ, R., Nasledno pravo, Altera, Beograd, 2010., str. 48.

5 BIKIĆ, E., SULJEVIĆ, S., Nasljedno pravo, Planjax komerc, Zenica, 2014., str. 131.

6 ROMAC, A., Rimsko pravo, Pravni fakultet, Zagreb, 1998., str. 432. - 433. 
Tražilo se, također, postojanje sedam svjedoka koji oporuku nisu trebali potpisati, ali je oporučitelj bio obvezan pokazati svjedocima oporuku i pred njima izjaviti da je to njegova oporuka. Svjedoci su morali biti odrasli rimski građani, neporočni, djelatno sposobni muškarci. Nisu smjeli biti bliži srodnici niti podređeni vlasti ostavitelja. Za pravljenje oporuke tražilo se da svjedoci budu posebno pozvani (testes rogati) te da svi zajedno nazoče tom činu. Dakle, tražilo se jedinstvo mjesta i vremena (unitas actus). ${ }^{7} \mathrm{Za}$ oporuku nepismenih i slijepih trebalo je pozvati još jednog (osmog) svjedoka, koji bi za nepismenog potpisao oporuku (octavus testis subscriptor), dok bi za slijepog on i pročitao i supotpisao oporuku. ${ }^{8}$

Ovakav oblik vlastoručne oporuke značajno se razlikuje od njene suvremene inačice. ${ }^{9}$ No, rimsko pravo je poznavalo i oporuku sličniju suvremenoj holografskoj oporuci, pod nazivom testamentum parentum inter liberos, odnosno tzv. privilegiranu oporuku ${ }^{10}$ kojom su roditelji ostavljali imovinu svojim potomcima. Ako je ova oporuka bila napravljena u pisanom obliku, svjedoci se nisu tražili. Bili su potrebni jedino kod usmenog oblika ove oporuke. ${ }^{11}$ Imenovanje nasljednika je bio bitan elemenat ili osnovni dio oporuke u rimskom pravu. Naime, prema rješenju klasičnog prava, ako bi oporuka sadržavala odredbe o ostavljanju legata, oslobađanju robova, postavljanju staratelja i sl., a ne i odredbu o postavljanju nasljednika, takve odredbe oporuke bi bile ništave. Odredbe oporuke kojom se ne postavlja nasljednik bile su ništave i u slučaju kada su navedene u oporuci prije no što je imenovan nasljednik. To imenovanje se trebalo obaviti upotrebom određenih riječi: heres (nasljednik) i esse (biti) u imperativu. ${ }^{12}$

U Bizantu, državno-pravnom sukcesoru Rimskog carstva, i dalje se primjenjivalo rimsko pravo (Justinijanov kodeks) i ono je, uz kasnije izmjene i dopune, ostalo u primjeni sve do pada Carigrada 1453. godine. Osim toga, pokoreno romansko stanovništvo nastavilo je, u međusobnim privatnopravnim odnosima, primjenjivati svoje običaje i pravo na prostoru nekadašnjeg Zapadnog Rimskog Carstva. Crkva je inzistirala na proširivanju slobode oporučivanja jer su joj

$7 \quad$ Ibid., str. 433.

$8 \quad$ Ibid., str. 434.

9 Usmena privatna oporuka pred sedam svjedoka uvedena je u III. stoljeću, dok je sredinom V. stoljeća prihvaćena holografska oporuka, oblik koji se danas koristi u većini suvremenih prava. Prema ANTIĆ, O. B., Nasledno pravo, Pravni fakultet Univerziteta u Beogradu, Beograd, 2007., str. 211.

$10 \quad$ SVORCAN, S., N., op. cit., str. 48.

11 BELAJ, V., op. cit., str. 15., bilješka br. 2

12 BABIĆ, I., Nasljedno pravo, Univerzitet u Banjoj Luci, Pravni fakultet, Banjaluka, 2012., str. 118. 
vjernici ponekad ostavljali neka materijalna dobra. Takva praksa se nastavila tijekom cijelog srednjeg vijeka. U to vrijeme, u Engleskoj, nije bilo uređene države. Sankcija u privatnopravnim odnosima nije bila izvjesna pa se svako pravljenje oporuke završavalo prijetnjom prokletstvom prema onome tko ga ne bude poštovao. Oporuka se sastojala od tri dijela: u prvom se vršilo objavljivanje (notificatio), drugi dio je sadržavao određivanje nasljednika i njegovog dijela, dok je treći dio sadržavao prijetnju božanskom sankcijom (sanctio). Razvijeniji srednji vijek uvodi princip teritorijalnosti prava (umjesto principa personalnosti). Tako su se nepisani običaji, koji su bili različiti za različite vrste i kategorije stanovništva, postajali pisani i u određenoj mjeri općeobvezatni. Oporučno pravo se tada sve više razvijalo pronalazeći svoje mjesto u pisanim običajima (npr. običaji Burgundskog vojvodstva, Arrasa, Hesdina, Douai et Horchies...). ${ }^{13}$

\section{Normativno određenje vlastoručne oporuke}

Holografska oporuka, prema važećem $\mathrm{ZN} \mathrm{FBiH},{ }^{14}$ pravovaljana je ako ju je oporučitelj napisao svojom rukom i ako ju je potpisao. Za pravovaljanost oporuke nije nužno da je u njoj naznačen datum kada je sačinjena, ali je poželjno pisanje istog kako bi se lakše utvrdilo je li to posljednja volja oporučitelja. ${ }^{15}$ Razlozi poželjnosti pisanja datuma su brojni. Tako, budući da holografska oporuka nema svjedoka, nedostatak datuma onemogućuje utvrđivanje je li oporučitelj u vrijeme sastavljanja oporuke imao oporučnu sposobnost. Osim toga, ako postoji više oporuka bez datuma, ne može se utvrditi pravovaljanost oporuke u materijalnom smislu (onemogućena je primjena pravila da kasnija oporuka ukida djelovanje ranije u mjeri u kojoj se njen sadržaj razlikuje od one koja je prije napisana). Naime, ako se kasnijom oporukom izričito ne opozove ranije napisana oporu$\mathrm{ka}$, odredbe ranije oporuke ostaju na snazi ako nisu u suprotnosti s odredbama kasnije oporuke. ${ }^{16}$ Pisanje datuma na holografskoj oporuci, također, pravi jasnu granicu između nacrta oporuke i posljednje volje oporučitelja, kao konačnog i valjanog akta. ${ }^{17}$

Na sličan način i drugi važeći zakoni o nasljeđivanju u Bosni i Hercegovini normiraju holografsku oporuku. Tako, prema odredbama ZN RS-a holografska

\footnotetext{
13 Više o tome: ANTIĆ, O. B., op. cit., str. 212. - 213.

14 V. čl. 66. st. 1. ZN FBiH.

V. čl. 66. st. 2. ZN FBiH.

16 PEZO, V. (gl. ur.), Odrednica: Vlastoručna oporuka, op. cit., str. 1767.

17 ANTIĆ, O., B., op. cit., str. 265.
} 
oporuka je pravovaljana ako ju je oporučitelj napisao svojom rukom i potpisao te stavio datum koji je, u ovom slučaju, nužan za njenu pravovaljanost. ${ }^{18} \mathrm{ZN} B D$ $\mathrm{BiH}$, gotovo na istovjetan način kao i $\mathrm{ZN} \mathrm{FBiH}$, regulira holografsku oporuku. ${ }^{19}$ Zakon o nasljeđivanju Republike Hrvatske, ${ }^{20}$ također, holografsku oporuku određuje kao oporuku koja je pravovaljana ako ju je oporučitelj vlastoručno napisao i ako ju je potpisao. Za valjanost oporuke nije nužno, ali je korisno napisati mjesto i datum kada je sastavljena. Također, prema Zakonu o nasljeđivanju Republike Srbije, ${ }^{21}$ kaže se da oporučitelj, koji zna čitati i pisati, može sačiniti holografsku oporuku tako što će ju svojom rukom napisati i potpisati. Pisanje datuma sastavljanja oporuke nije nužno za njezinu pravovaljanost, ali je poželjno. Tako je i u Zakonu o nasljeđivanju Crne Gore. ${ }^{22}$ Najveće svjetske kodifikacije građanskog prava slično definiraju holografsku oporuke. Prema čl. 970. Code Civila za pravovaljanost holografske oporuke se traži da je napisana i potpisana u cijelosti od ostavitelja te da je datirana. ${ }^{23}$ Prema $₫ 2247$ njemačkog Građanskog zakonika, ostavitelj treba vlastoručno napisati i potpisati holografsku oporuku, navodeći datum i mjesto njenog sastavljanja. ${ }^{24} \S 578$ austrijskog Građanskog zakonika kaže da holografsku oporuku oporučitelj treba sam napisati i potpisati, pri čemu datum i mjesto sastavljanja nisu nužni, ali su preporučljivi. ${ }^{25}$ Čl. 505 švicarskog Građanskog zakonika, također, traži da holografska oporuku bude napisana i potpisana od oporučitelja, uz navođenje datuma pisanja oporuke. ${ }^{26} \mathrm{U}$ čl. 602. talijanskog Građanskog zakonika stoji da holografska oporuka mora biti u cijelosti napisana, datirana i potpisana rukom oporučitelja. Potpis mora biti stavljen na

18 V. čl. 68. ZN RS.

19 V. čl. 70. ZN BD BiH.

V. čl. 30. Zakona o nasljeđivanju Republike Hrvatske, Narodne novine, br. 48/03., 163/03., 35/05., 127/13., 33/15. i 14/19. (dalje u tekstu: ZN RH).

V. čl. 84. Zakona o nasleđivanju Republike Srbije, Službeni glasnik RS, br. 46/95., 101/03. - odluka USRS i 6/15. (dalje u tekstu: ZN SR).

V. čl. 66. Zakona o nasljeđivanju Crne Gore, Službeni list Crne Gore, br. 74/08., 75/17. odluka US, dalje: ZN CG

V. čl. 970. Code Civilea, dostupno na: Code civil: Chapitre V: Des dispositions testamentaires. (Articles 967 à 1047), https://www.legifrance.gouv.fr/codes/section_lc/LEGITEXT000006070721/LEGISCTA000006136338/\#LEGISCTA000006136338, (24. 9. 2021.). V. $\$ 2247$ njemačkog Građanskog zakonika, dostupno na: Bürgerliches Gesetzbuch Eigenhändiges Testament, https://dejure.org/gesetze/BGB/2247.html, (24. 9. 2021.).

$\$ 578$ ABGB dostupno na: ABGB - Allgemeines bürgerliches GesetzABGB - Allgemeines bürgerliches Gesetzbuch Beobachtenmerken, https://www.jusline.at/gesetz/abgb/paragraf/578, (24. 9. 2021.). https://www.fedlex.admin.ch/eli/cc/24/233_245_233/de\#art_505, (24.9. 2021.). 
kraj oporučnih odredbi. Dodaje se da i ako oporuka nije sastavljena s naznakom imena i prezimena oporučitelja, ipak će biti pravovaljana ako sa sigurnošću označava njegovu osobu. ${ }^{27}$ Holografska oporuka se pak ne može pronaći, primjerice, u pravu Kraljevine Nizozemske i Republike Portugal, gdje je uvijek nužno sudjelovanje notara kada dođe do sačinjavanja oporuke. ${ }^{28}$

Za pravovaljanost oporuke nije bitno kojim je jezikom ili pismom napisana. Osim materinskog jezika, to može biti bilo koji strani jezik ili tzv. "neživi" jezik poput latinskog i starogrčkog, odnosno bilo koje oporučitelju poznato pismo. Prirodni i redni brojevi napisani brojkama u oporuci nisu pravno nevaljani zato što nisu napisani slovima. ${ }^{29}$ Za pravovaljanost holografske oporuke irelevantno je, također, je li njen sadržaj očitovan na papiru ili drugoj podlozi tintom ili olovkom. Ona može biti napisana na bilo kojem materijalu i bilo kojim sredstvom, premda će to najčešće biti papir i olovka (grafitna, kemijska, nalivpero itd.). Zbog toga sadržaj oporuke može biti sačinjen i u obliku pisma koje roditelj upućuje svom djetetu. ${ }^{30}$ Oporuku je moguće napisati kredom na vratima ili zidu, ili u nekoj knjizi itd. Međutim, odabir neobičnog materijala ili sredstva za pisanje holografske oporuke može izazvati sumnju u ozbiljnost oporučiteljeve posljednje volje, što može dovesti do poništenja oporuke. Tu bi moglo doći do osporavanja oporučiteljeve sposobnosti za rasuđivanje. Tako, ako oporučitelj, u uobičajenim okolnostima, u svojoj radnoj sobi napiše oporuku kredom na zidu, umjesto olovkom na papiru (koju je imao u sobi), oporuka neće biti valjana jer oporučitelj, primjerice, nije bio sposoban za rasuđivanje ili je postojao nedostatak namjere za pravljenje oporuke (animus testandi i sl.). ${ }^{31}$ Sumnje ne bi trebalo biti onda kada su okolnosti u kojima je oporuka nastala primjerene odabiru materijala i sredstva za pisanje (npr. pojava iznenadne bolesti, boravak na izoliranom mjestu i sl.), ${ }^{32}$ odnosno kada u slučaju potresa, oporučitelj nekim predmetom napiše svoju posljednju volju na zidu, ili je ureže na pećinu u kojoj je zameten i sl. ${ }^{33}$

27 V. čl. 602. talijanskog Građanskog zakonika, dostupno na: Codice Civile, LIBRO SECONDO, TITOLO III DELLE SUCCESSIONI, CAPO IV Della forma dei testamenti Sezione I Art 602, Testamento olografo, https://www.ricercagiuridica.com/codici/vis.php?num=9071, (23. 9. 2021.).

HARTKAMP, A. et al. (Eds.), Towards a European Civil Code, Kluwer Law International, Alphen aan den Rijn, 2011., str. 467.

BABIĆ, I., op. cit., str. 130.

V. Presudu Vrhovnog suda Srbije, Rev. 2488/96, Glasnik pravde 2,3,4/99-119.

ANTIĆ, O., B., op. cit., str. 266.

BELAJ, V., op. cit., str. 15.

ANTIĆ, O., B., op. cit., str. 266. 
Ako je oporuka nastala u inozemstvu, onda treba voditi računa o eventualnoj primjeni pravila locus regit actum. Holografska oporuka nastala u inozemstvu mogla bi biti valjana ako i ne udovoljava pretpostavkama koje zahtijeva domaće pravo. Tu je važno ispunjenje pretpostavke valjanosti prema pravu države u kojoj je nastala ${ }^{34}$ jer "oporuka sastavljena u inozemstvu pravno je valjana glede oblika, uz ostalo, i onda ako je valjana po pravu mjesta gdje je sastavljena." ${ }^{35}$

\section{Vlastoručno pisanje oporuke}

Vlastoručno pisanje oporuke, predstavlja jamstvo slobode volje, ali i zaštitu od mogućih zloupotreba. ${ }^{36}$ Sastavljanje oporuke u tajnosti omogućava oporučitelju potpuno izražavanje slobodne volje te izbjegavanje pritisaka nesavjesnih nasljednika koji, na ovaj način, nemaju saznanja o postojanju oporuke niti za njen sadržaj. ${ }^{37}$ Sigurnost holografske oporuke sadržana je u pouzdanoj identifikaciji rukopisa oporučitelja. ${ }^{38}$ Najvažnije prednosti holografske oporuke su potpuna tajnost sadržaja i sigurnost koja joj se značajno uvećava ako ju se preda na čuvanje sudu ili drugom subjektu u zatvorenoj omotnici. U tom slučaju, oporuka ostaje i dalje poznata samo oporučitelju. Činjenice o sastavljanju, pohranjivanju, opozivu i proglašenju ove oporuke mogu se, ali i ne moraju dostaviti u registar oporuka. ${ }^{39}$ Osim toga, holografsku oporuku je moguće napraviti u bilo koje doba, na vrlo jednostavan način i uz minimalne troškove. ${ }^{40}$ Pristupačnost ovog jednostavnog oblika, osim nedvojbenih prednosti, ima i svoje nedostatke. Tako, moguće je, u smislu mana volje, izvršiti nedopušten utjecaj na npr. mlađe osobe, što je teško dokazivo. Zbog toga njemačko pravo predviđa da maloljetne osobe ne mogu sastavljati holografsku oporuku ( $\$ 2247$ st. 4 BGB-a). ${ }^{41}$

$34 \quad$ BELAJ, V., op. cit., str. 16.

Vrhovni sud RH, Gzz 28/1992-2 dostupno na: Prilozi Hrvatske javnobilježničke komore, Institut oporučnog nasljeđivanja u sudskoj praksi, dostupno na: https://www. hjk.hr/Portals/0/CasopisJB/Prilog\%20uz\%20br\%2036.pdf?ver=K-AGHRoSwepVU1Ko0ZG88Q\%3d\%3d, (26. 9. 2021.).

MARKOVIĆ, S., Nasledno pravo u Jugoslaviji, Savremena administracija, Beograd, 1978., str. 205.

SVORCAN, S. N., op. cit., str. 48.

SANCHEZ, E., Are we ready for electronic wills?, Notes on business education, Vol. 9., Iss. 2., Manila, 2006., str. 3.

$41 \quad$ V. $\$ 2247$ njemačkog Građanskog zakonika, dostupno na: Bürgerliches Gesetzbuch E i genhändiges Testament, https://dejure.org/gesetze/BGB/2247.html, (24. 9. 2021.). 
Po samoj svojoj prirodi, holografska oporuka mora zadržati, kao uvjet svoje pravovaljanosti, vlastoručno pisanje. Riječ je o vlastoručnom sastavljanju cjelokupne oporuke tehnikom pisanja koja se zove rukopis. Oporučitelj je treba napisati svojom rukom (oblikovati slova) i potpisati je. ${ }^{42}$ To je, ujedno, jamstvo oporučiteljevog neposrednog očitovanja volje. Zahtjev vlastoručnosti će biti zadovoljen i ako je oporučitelj pisao protezom i sl. ${ }^{43}$ Bez zahtjeva vlastoručnosti holografska oporuka gubi smisao svog postojanja u općem sustavu oporuka. ${ }^{44} \mathrm{Za}$ oporuku pak koja je napisana rukom oporučitelja, ali tiskanim slovima, nailazi se na različite stavove pravnih teoretičara. Jedni tvrde da ona neće biti pravovaljana kao holografska oporuka, jer u procesu njenog sastavljanja nije sudjelovao nitko tko bi mogao potvrditi da je oporuku pisao točno određeni oporučitelj. Ako bi se nakon smrti oporučitelja takva činjenica javila kao sporna, jedini pouzdan dokaz koji ukazuje na to tko je pisao oporuku jesu karakteristike samog rukopisa. ${ }^{45}$ Drugi pravni teoretičari sastavljanje holografske oporuke tiskanim slovima smatraju nespornim. ${ }^{46} \mathrm{Na}$ takav stav se nailazi i u sudskoj praksi zemalja regije. ${ }^{47}$

Nevaljana je oporuka napisana od oporučitelja računalom ili pisaćim strojem nakon čega je vlastoručno potpisana, ${ }^{48}$ o čemu svjedoči i sudska praksa. ${ }^{49}$ Inače, pisanje oporuke uz korištenje raznih tehničkih sredstva, odnosno sredstava koja će ostaviti otisak unaprijed oblikovanih slova (računalo, pisač, pisaći stroj, razni šabloni itd.) ne može proizvesti pravne učinke i biti pravovaljana, bez obzira na

42 V. presudu Vrhovnog suda RCG, Rev. br. 566/95, Glasnik pravde 5/00-221.

43 GAVELLA, N.; BELAJ, V., Nasljedno pravo, Narodne novine, Zagreb, 2008., str. 145.

${ }_{44} \quad$ KAŠĆELAN, B., Svojeručno zaveštanje u italijanskom pravu, Godišnjak Pravnog fakulteta u Istočnom Sarajevu, god. 1., br. 1., Istočno Sarajevo, 2010., str. 145.

SVORCAN, S., Nasledno pravo, Pravni fakultet u Kragujevcu, Institut za pravne i društvene nauke, Kragujevac, 2009., str. 47.

V. STOJANOVIĆ, N., Nasledno pravo, Pravni fakultet Univerziteta u Nišu, Centar za publikacije, Niš, 2011., str. 212.

Oporuka napisana velikim vlastoručno tiskanim slovima (tzv. tehničko pismo), te koja je na taj način i potpisana, pravno je valjana oporuka (i to kad se radi o oporučitelju koji se u pravnom prometu i privatno koristio, kako pisanim, tako i tiskanim slovima). Pošto je oporuka napisana rukom oporučitelja, pretpostavka za pravnu valjanost vlastoručne oporuke je tu. Presuda Vrhovnog suda RH, Rev-1226/07-2 od 21. 5. 2008., dostupno na: https://sudskapraksa.csp.vsrh.hr/decisionPdf?id=090216ba80557a24 (28. 7. 2021.).

BULKA, Z., Nasljeđivanje na temelju oporuke, Hrvatska pravna revija, god. 10., br. 12., Zagreb, 2010., str. 55.

V. rješenje Županijskog suda u Varaždinu, Gž-527/03-2 od 12. 5. 2003., dostupno na: http://www.sudacka-mreza.hr/odluke.aspx?Search=oporuka\&Search $2=\&$ Court $=---\&$ Typ e $=---\&$ Type $1=---\&$ Type 1 a $=---\&$ Type $2=---\&$ Typ e2a $=--\&$ Type $3=\&$ Type $4=\& \mathrm{O} 1=\& \mathrm{O} 2=\& \mathrm{O} 3=\& \mathrm{O} 4=\& \mathrm{P} 1=\& \mathrm{P} 2=\&$ ShowID=22672 (28. 7. 2021.). 
to što se oporučitelj prilikom korištenja tehničkih sredstava služio svojim rukama. Tu, jednostavno, nije ispunjen zahtjev vlastoručnosti jer se ne radi o rukopisu. ${ }^{50}$ Nevaljana je i oporuka napisana vlastoručno od druge osobe, a po diktatu oporučitelja. ${ }^{51} \mathrm{Ne}$ smatra se pravovaljanom oporukom niti preslika vlastoručno napisane oporuke. ${ }^{52}$ Naime, oporuka je formalni akt od kojeg nema odstupanja. Presliku oporuke oporučitelj nije vlastoručno napisao i potpisao. ${ }^{53}$

Pravovaljana holografska oporuka može biti samo oporuka čiji je cjelokupni sadržaj napisao oporučitelj osobno, bez pomoći drugih osoba. Ako su pojedini dijelovi oporuke pisani drugim načinom, posebice od drugih osoba, takva oporuka neće proizvoditi pravne učinke, bez obzira na to je li oporučitelj s time bio upoznat ili ne. ${ }^{54}$ Određena manja odstupanja od predviđenog pravila postoje, $\mathrm{s}$ obzirom na to da vanjska pomoć i vanjski savjeti nisu apsolutno isključeni. ${ }^{55}$

Budući da je oporuka ostaviteljev jednostrani pravni posao, mortis causa, koji se nakon smrti ne može nadopuniti, izmijeniti ili na drugi način popraviti, nasljednopravna uređenja se rukovode načelom in favorem testamenti smatrajući oporuku valjanom, ako je sastavljena u bilo kojem obliku koji zakon predviđa, bez obzira na to je li ostavitelj htio baš taj oblik. Tako, primjerice, kada je ostavitelj vlastoručno napisao i pred svjedocima potpisao oporuku, pri čemu je jedan od svjedoka bio supružnik, takva oporuka nije ispunila pretpostavke za valjanost pisane oporuke pred svjedocima, ali je ispunila pretpostavke za valjanost holografske oporuke jer ju je oporučitelj vlastoručno napisao i potpisao. ${ }^{56}$ "Oporuka koju je oporučitelj napisao svojom rukom i potpisao pravovaljana je te za taj oblik oporuke nisu potrebne nikakve druge formalnosti, ali ako su iste ipak učinjene (ovdje potpisi svjedoka), one same po sebi ne oduzimanju oporuci značenje valjane vlastoručne oporuke. Potpisi svjedoka na vlastoručnoj oporuci ne daju toj oporuci značenje pisane oporuke pred svjedocima." ${ }^{7}$

$50 \quad$ GAVELLA, N., BELAJ, V., op. cit., str. 145.

51 ĐURĐEVIĆ, D., Institucije naslednog prava, JP Službeni glasnik, Beograd, 2012., str. 132. V. presudu Vrhovnog suda RH, Rev-1261/91-2 od 29. 10. 1991., dostupno na: https://sudska praksa.csp.vsrh.hr/decisionPdf?id=090216ba8022715d (29. 7. 2021.).

Presuda Vrhovnog suda FBiH broj: 680 P 00246216 Rev od 19. 1. 2017. godine, dostupno na: Nasljedno pravo - sudska praksa Bosne i Hercegovine, https://advokat-prnjavorac. com/nasljedno-pravo-sudska-praksa-BiH.html, (26. 9. 2021.). SILAJDŽIĆ, A., Nasljedno pravo, Univerzitet u Sarajevu, Sarajevo, 1964., str. 163. BINDER, J., Bürgerliches Recht, Erbrecht, Springer-Verlag GmbH, Berlin, Heidelberg, 1923. str. 9. - 10. PEZO, V. (gl. ur.), Odrednica: Oporuka, konverzija oblika, op. cit., str. 949. praksi, https://legalis.hr/blogs/entry/58-oporuka-u-sudskoj-praksi/, (26. 9. 2021.). 


\subsection{Tjelesne poteškoće oporučitelja i vanjska pomoć u kontekstu zahtjeva vlastoručnosti}

Kada je riječ o tjelesnim poteškoćama oporučitelja, može se dogoditi da oporučitelj teško piše zbog slabosti odnosno bolesti jer su mu npr. oboljele ruke. Iz takvih razloga oporučitelj može zatrebati pomoć neke druge osobe. Tako, prilikom sačinjavanja oporuke druga osoba mu može pridržavati ruku, čime se smanjuje drhtanje iste. Na takav način sastavljena oporuka bit će pravovaljana, pod uvjetom da se u rukopisu oporučitelja očuvaju njegove bitne karakteristike, iz kojih se može potvrditi autentičnost oporuke. ${ }^{58}$ Prethodno konsultiranje druge osobe po pitanju sadržaja oporuke, također, ne utječe na njezinu pravovaljanost. ${ }^{59}$ Razne pripreme za sastavljanje oporuke, kao što je korištenje obrazaca, pravljenje nacrta i sl., neće utjecati na pravnu valjanost holografske oporuke, pod uvjetom, da ju je vlastoručno napisao oporučitelj. ${ }^{60}$ Oporuka koju je u izvorniku, kao konačnu, napisao i potpisao oporučitelj bit će pravovaljana čak i ako je nacrt iste oporučitelju sastavila druga osoba, a oporučitelj ga je prepisao. Najvažnije je da završni sastav oporuke predstavlja svjesno izjavljenu i slobodnu volju njenog oporučitelja. ${ }^{61}$ To proizlazi iz odredbi Zakona o obveznim odnosima, ${ }^{62}$ kojim se jasno propisuje da izjava volje mora biti učinjena slobodno i ozbiljno, ${ }^{63}$ sukladno odgovarajućim nasljednopravnim odredbama. ${ }^{64}$

Oporuka je krivotvorena (lažna) ako je akt oporučivanja poduzeo sam oporučitelj, na način da se netko drugi poslužio njime kao sredstvom za očitovanje volje. To se može dogoditi kada netko, koristeći silu, oporučiteljevim tijelom izvrši onu radnju kojom se inače očituje volja. Primjerice, netko uzme ruku oporučitelja pa je pokreće svojom snagom, bez ili protiv oporučiteljeve volje te na takav način

SVORCAN, S., Komentar Zakona o nasleđivanju Srbije: sa sudskom praksom, Pravni fakultet Kragujevac, Kragujevac, 2004., str. 206., dalje u tekstu: Komentar...

BLAGOJEVIĆ, B., PEROVIĆ, S., STANKOVIĆ, O., Nasledno pravo SFRJ: sa osvrtom na prava drugih država, Zavod za izdavanje udžbenika Socijalističke Republike Srbije, Beograd, 1964., str. 240.

BABIĆ, I., Komentar Zakona o nasleđivanju: sa odabranom sudskom praksom i prilozima, Službeni glasnik, Beograd, 2013., str. 260.

KREČ, M., PAVIĆ, Đ., Komentar Zakona o nasljeđivanju (sa sudskom praksom), Narodne novine, Zagreb, 1964., str. 204. Službeni glasnik Republike Srpske br. 17/93, 3/96, 39/03, 74/04., dalje: ZOO.

V. čl. 28. st. 2. ZOO.

V. čl. 62.-63. ZN FBiH, čl. 64.-65. ZN RS i čl. 66.-67. BD BiH. 
napiše tekst, potpiše oporuku ili se posluži hipnozom ili drugim postupkom zbog kojega oporučitelj daje očitovanje koje nije njegova volja. Ovakva oporuka ne proizvodi pravne učinke valjane oporuke, ali izaziva određene kaznenopravne, kao i nasljednopravne učinke (krivotvoritelj će biti nedostojan naslijediti ostavitelja, kako na temelju oporuke, tako i na temelju zakona). ${ }^{65}$

Za sastavljanje holografske oporuke potrebno je da oporučitelj zna čitati i pisati te da može pisati. ${ }^{66}$ Radi cjelovitog određenja ovog osnovnog uvjeta ispravno bi bilo reći da oporučitelj, osim toga što mora znati i moći pisati te znati čitati, mora i moći čitati (zbog npr. preveniranja raznih zloupotreba). Najbolje to objašnjava primjer slijepih oporučitelja. ${ }^{67}$ Svaki građanin može praviti javnu oporuku, ali onaj tko ne zna čitati i pisati ili ne može čitati i pisati mora praviti javnu oporuku. U protivnom, oporuka je nevaljana. ${ }^{68}$ Ovaj stav uporište nalazi i u sudskoj praksi. ${ }^{69}$ Međutim, ima teoretičara koji smatraju da slijepa osoba može sastaviti pravovaljanu holografsku oporuku. ${ }^{70}$ Navodi se kako se holografskom oporukom mogu služiti sve pismene osobe, bez obzira na to jesu li slijepe ili imaju li određene vidove deformiteta prstiju i ruku, ako se koriste odgovarajućim pomagalima, protezama i sl. ${ }^{71}$ Premda slijepe osobe često znaju i čitati i pisati jer je njihova sljepoća nastupila nakon što su postale pismene, one ne mogu čitati. ${ }^{72}$ Bez obzira na činjenicu što oporučitelj oporuku nije u stanju pročitati, isti smatraju da su ispunjeni zakonski uvjeti u pogledu valjanosti holografske oporuke ako su je navedene osobe bile u mogućnosti vlastoručno napisati i potpisati. ${ }^{73}$

Holografska oporuka ne može biti sastavljena tehničkim sredstvom koje će imati ulogu posrednika između ruke oporučitelja i materijala na kome se ona piše. S druge pak strane, ako oporučitelj koji nema ruke za pisanje upotrijebi mehaničku ruku ili čak zdravu nogu ${ }^{74}$ te tako sastavi holografsku oporuku, na način na koji

PEZO, V. (gl. ur.), Odrednica: Oporuka, krivotvorena, str. 949.

VEDRIŠ, M., KLARIĆ, P., Građansko pravo, Narodne novine, Zagreb, 2014., str. 738.

"Kao osoba koja ne zna čitati ili pisati smatra se i onaj koji nije u stanju čitati i pisati..." Vrhovni sud, Gž-584/66. od 14. 9. 1966. prema CRNIĆ, J., op. cit, str. 102.

VEDRIŠ, M; KLARIĆ, P, op. cit., str. 741.

"Kao osoba koja ne zna čitati ili pisati smatra se i onaj koji nije u stanju čitati i pisati..." Vrhovni sud, Gž-584/66. od 14. 9. 1966. prema CRNIĆ, J., op. cit., str. 102.

V. odluke Vrhovnog suda Srbije Gž 2108/59 i Saveznog vrhovnog suda, Rev. br. 1881/60 te presudu Vrhovnog suda Jugoslavije, Rev. br. 97/65. prema ANTIĆ, O. B., op. cit., str. 267. BAGO, D. et al., Osnovi nasljednog prava, PP „To je to“, Sarajevo, 1991., str. 77.

Slično: KREČ, M., PAVIĆ, Đ., op. cit., str. 203.

Ibid.

Ako se radi o oporučitelju koji nema ruke ili prste, oporuka može biti napisana i potpisana i ustima. Međutim, opravdanost, kao i dopuštenost odstupanja od ustaljenih načina pisa- 
se u pravnom prometu smatra da je vlastoručno napisana, radit će se o pravovaljanoj oporuci. ${ }^{75}$

\subsection{Stenografija i zahtjev vlastoručnosti}

Kada se govori o pravnoj valjanosti holografske oporuke sastavljene rukopisom oporučitelja, ali stenografijom, ${ }^{76}$ nailazi se na više stajališta. Svrha stenografije bila bi, prije svega, brzo pisanje a takvim se pisanjem obično prave nacrti određenih akata. Ako je oporuka napisana stenografski, može se posumnjati da se, u konkretnom slučaju, radi o nacrtu oporuke, odnosno o aktu koji nema animus testandi. Međutim, moguće su i situacije u kojima oporučitelj nije u mogućnosti izbjeći nečiju nazočnost i sastaviti oporuku u privatnosti. U tom slučaju se može poslužiti stenografijom, prikrivajući sadržaj sastavljene oporuke. Zbog svega toga pravna valjanost oporuke pisane stenografski ovisit će o okolnostima svakog konkretnog slučaja. Ako dođe do spora, na sudu je da sve podrobno ispita. ${ }^{77}$ Također, smatra se kako je stenografski napisana i potpisana oporuka valjana, ali pod uvjetom da je primijenjena neka od usvojenih stenografskih metoda. Naime, stenogram predstavlja rukopis osobe koja se njime služi te tako sadrži osobno obilježje autora. ${ }^{78}$ Suprotno ovome, postoje i stajališta da se iz teksta pisanog stenografskim znacima ne mogu jasno vidjeti bitne karakteristike rukopisa oporučitelja zbog čega oporuka pisana vlastoručno, ali stenografijom ne može biti pravovaljana. ${ }^{79}$

\section{Vlastoručno potpisivanje oporuke}

Oporučiteljev potpis mora biti na ispravi na kojoj je oporuka sačinjena. Bitna pretpostavka pravne valjanosti holografske oporuke jest autentičnost potpisa na istoj. Što se tiče njegovog položaja na ispravi, on mora biti na koncu teksta

nja, uvijek se mora procjenjivati prema okolnostima slučaja. KREČ, M., PAVIĆ, Đ., op. cit., str. 202.

ANTIĆ, O. B., Nasledno pravo, Pravni fakultet Univerziteta u Beogradu, Centar za izdavaštvo i informisanje, Beograd, 2014., str. 284.

Stenografija je način pisanja osobitim znakovima i mnogim kraticama koji omogućuje brzo bilježenje usmenog govora; brzopis. V. KLAIĆ, B., Odrednica: Stenografija, Rječnik stranih riječi, Školska knjiga, Zagreb, 2007. str. 1264.

Ibid.

V. KREČ, M., PAVIĆ, Đ., loc. cit; GAVELLA, N., Nasljedno pravo, Informator, Zagreb, 1986., str. 171. 
oporuke, ispod ili desno od posljednje riječi oporuke. ${ }^{80}$ "Vlastoručna oporuka je pravovaljana ako ju je oporučitelj napisao svojom rukom i ako ju je potpisao. Pritom potpis oporuke mora uslijediti nakon što se ona napiše, dakle, na kraju oporuke." ${ }^{11}$ Sve što bi se eventualno napisalo ispod potpisa u oporuci, ne proizvodi pravne učinke. Ovo se ne odnosi na datum i mjesto sastavljanja oporuke koji se mogu naći ispod potpisa. ${ }^{82}$ Stavljanjem potpisa oporučitelj označava završetak ispisivanja svoje volje u smislu raspolaganja svojom imovinom mortis causa (bilo dijelom, bilo čitavom imovinom) te istim potvrđuje ono što je napisano. ${ }^{83} \mathrm{Smi}$ sao potpisa jest potvrđivanje da tekst oporuke, sadržan iznad njega, predstavlja doista posljednju volju oporučitelja, ${ }^{84}$ da se radi o ozbiljno izraženoj i formiranoj volji, a ne tek nekom nacrtu raspolaganja. Potpis prostorno zatvara tekst oporuke ukazujući na njezinu cjelovitost. ${ }^{85}$

Potpis može biti determiniran i kao conditio sine qua non valjanosti pa se oporuka neće smatrati dovršenom ako nema potpisa. Čitljivost potpisa ne predstavlja uvjet valjanosti oporuke. ${ }^{86}$ Holografska oporuka mora biti potpisana vlastoručno, ${ }^{87}$ a poželjno je i uobičajeno da je potpisana punim imenom i prezimenom. ${ }^{88}$ Sukladno Zakonu o osobnom imenu, ${ }^{89}$ potpisivanje oporuke se vrši punim imenom i prezimenom, ${ }^{90}$ ali moguća su i određena odstupanja, odnosno drukčije

80 ĐURĐEVIĆ, D., op. cit., str. 134.

81 Vrhovni sud RH, Rev 1330/2008-2 od 17. 2. 2010. dostupno na: Oporuka u sudskoj praksi, https://legalis.hr/blogs/entry/58-oporuka-u-sudskoj-praksi/, (26. 9. 2021.). ĆERANIĆ, D., op. cit., str. 45. POČUČA, M., Nasledno pravo, Pravni fakultet za privredu i pravosuđe Novi Sad, Novi Sad, 2012., str. 158.

V.presuduVrhovnogsudaRH,Rev-949/94-2od18.5.1995.,dostupnona:https://sudskapraksa. csp.vsrh.hr/decisionPdf?id=090216ba8025078d (3. 8. 2021.).

FRANK, R., Erbrecht, C.H. Beck'sche Verlagsbuchhandlung, München, 2000., str. 62. KREČ, M., PAVIĆ, Đ., loc. cit.

Vlastoručni potpis, odnosno, potpis imena svojom rukom, potpis je obiteljskog i rodnog imena. V. presudu Općinskog suda u Opatiji, P-180/03-16 od 29. 12. 2003., dostupno na: http://www.sudacka-mreza.hr/odluke.aspx?Search=oporuka\&Search2=\&Court=--\&Type=---\&Type1=---\&Type1a=---\&Type2=---\&Type2a=---\&Type3=\&Type4=\&O1=\& $\mathrm{O} 2=\& \mathrm{O} 3=\& \mathrm{O} 4=\& \mathrm{P} 1=\& \mathrm{P} 2=\&$ ShowID $=23832$ (3. 8. 2021.). ĐURĐEVIĆ, D., loc. cit.

Zakon o osobnom imenu, Službene novine FBiH, br. 7/12. (dalje u tekstu: ZOI FBiH), Zakon o ličnom imenu RS, Službeni glasnik RS, br. 82/19. (dalje u tekstu: ZOI RS), Zakon o ličnom imenu BD, Službeni glasnik BD BiH, br. 08/02, 29/05. (dalje u tekstu: ZOI BD $\mathrm{BiH})$.

Državljanin $\mathrm{BiH}$, odnosno $\mathrm{FBiH}$, obvezan je u pravnom prometu služiti se osobnim imenom upisanim u matičnu knjigu rođenih. Osobno ime sastoji se od imena i prezimena, 
formuliranje potpisa. ${ }^{91}$ Temeljem potpisa mora biti moguće nedvojbeno potvrditi oporučiteljev identitet. Najbolje je koristiti se istim potpisom koji se koristi u pravnom prometu, poput onoga na identifikacijskim ispravama (npr. osobna iskaznica, putovnica i sl.), odnosno onim koji je sadržan u bazi podataka nadležnih tijela koja izdaju predmetne isprave. ${ }^{92}$ Iznimno je bitno da potpis oporučitelja uvijek bude učinjen animo testandi, odnosno s namjerom sastavljanja oporuke.

Oporučitelj može ovjeriti svoj potpis. Oporuka time ne postaje javna, nego je i dalje privatna. ${ }^{93} \mathrm{Na}$ taj način se, u određenoj mjeri, smanjuje mogućnost spora u pogledu originalnosti rukopisa i potpisa oporučitelja. Radi veće sigurnosti, ispod potpisa se mogu dodati i podaci iz neke od identifikacijskih isprava. ${ }^{94} \mathrm{Me}$ đutim, unošenje tih podataka kao i ovjera potpisa ne spadaju u elemente oblika kojeg propisuju zakonske nasljednopravne odredbe. ${ }^{95}$

Postoji mogućnost i da netko drugi pomogne slabom ili bolesnom oporučitelju kako bi mogao izvršiti akt potpisivanja ${ }^{96}$ pri čemu stavljanje potpisa mora izvršiti oporučitelj osobno. Potpis uvijek mora sadržavati osobine pisanja oporučitelja. Ako potpis ima osobine druge osobe, smatrat će se da je riječ o situaciji istovjetnoj onoj u kojoj neka osoba nije u mogućnosti potpisati ispravu. ${ }^{97}$

\subsection{Formuliranje potpisa oporučitelja}

Bez oporučiteljevog potpisa oporuka nije ništa više od nacrta, odnosno probnog izražavanja dispozitivnih želja. ${ }^{98}$ Primjerice, u čl. 602. talijanskog Gra-

dok se ime, kao i prezime, može sastojati od više riječi. Osoba čije se ime ili prezime, ili i ime i prezime, sastoji od više riječi, a koje su upisane u matičnu knjigu rođenih, u pravnom prometu će se obvezno služiti osobnim imenom, koje je upisano u matičnu knjigu rođenih. V. čl. 4.-5. ZOI FBiH. Isto određuje i čl. 3. ZOI RS te čl. 2. ZOI BD BH.

BAGO, D. et al., loc. cit.

BIKIĆ, E., SULJEVIĆ, S., loc. cit.

ANTIĆ, O., op. cit., str. 285.

STOJANOVIĆ, N., op. cit., str. 213.

V. čl. 66. ZN FBiH, čl. 68. ZN RS i čl. 70. ZN BD BiH.

"Pri potpisivanju oporuke može druga osoba slabom i bolesnom oporučitelju pomagati, ali i uz tu pomoć oporučitelj ipak mora oporuku potpisati vlastoručno." Vrhovni sud, Gž1033/79. od 17. 7. 1979. prema CRNIĆ, J., op. cit., str. 103.

ĐOKIĆ, D., Svojeručno i sudsko zaveštanje, Pravni informator, god. 14., br. 3., Beograd, 2011., str. 39.

RHODES, A-M., Notarized Wills, Quinnipiac Probate Law Journal, Vol. 27., No. 4., Hamden, 2014., str. 423. 
đanskog zakonika se izričito kaže da će biti pravovaljana oporuka koja nije sastavljena s naznakom imena i prezimena oporučitelja ako se sa sigurnošću može utvrditi njegova osoba. Ne treba dovoditi u pitanje pravovaljanost oporuke kod koje se može odrediti tko je oporučitelj jer u uvodu oporuke stoji ime i prezime, a na koncu oporuke je potpis koji sadrži samo prezime. Također, postoje mišljenja da se radi o ispravno potpisanoj oporuci ako je oporučitelj napisao samo svoje rođeno ime, ${ }^{99}$ ili ako se odredio rodbinskim odnosom prema osobama koje je u oporuci odredio za nasljednike. Pritom sadržaj oporuke ne smije stvarati nikakve dodatne sumnje po pitanju identiteta oporučitelja. ${ }^{100}$ Oporuci neće biti uskraćeni pravni učinci ako je oporučitelj ispod izjave posljednje volje, umjesto svog potpisa, naveo odnos srodstva prema nasljednicima izrazima poput „vaša majka“, „vaš otac", temeljem kojih se sa sigurnošću može utvrditi tko je tvorac oporuke. ${ }^{101}$ Ima i drukčijih stajališta koja kažu da oznaka rodbinskog odnosa (npr. teta) se ne smatra, prema prevladavajućoj sudskoj praksi, vlastoručnim potpisom oporuke, odnosno potpisom imena svojom rukom. ${ }^{102}$ Kao valjan potpis može se prihvatiti $\mathrm{i}$ ispisivanje poznatog pseudonima, kojeg je oporučitelj koristio kao umjetničko ime, ili pak stavljanje oporučiteljevog općepoznatog nadimka. Suprotno ovome, u svrhu potpisivanja ne može se koristiti i prihvatiti rukoznak, bez obzira na vrstu. ${ }^{103}$ To je odgovor pravnih teoretičara na pitanje sudske prakse koja je ispitivala valjanost holografske oporuke na koju je oporučitelj stavio rukoznak. ${ }^{104}$ Međutim, situacija će biti drukčija ako oporučitelj doda otisak prsta pored već stavljenog potpisa. U tom slučaju, neće se raditi o pravno nevaljanoj oporuci. ${ }^{105,106}$

'Drži se valjanom vlastoručnom oporukom pismeni sastav u kojem se navodi samo ime osobe kojoj se ostavlja sva imovina, a nije neizvjesno o kojoj se osobi radi, i koji sastav je potpisan samo ostaviteljevim imenom onako kako se ta osoba (ostavitelj) uobičajeno potpisivala iako nije stavila i porodično ime - prezime." Okružni sud u Karlovcu, Gž261/75). od 4. 6. 1976. prema CRNIĆ, J., op. cit., str. 101.

KREČ, M., PAVIĆ, Đ., loc. cit.

101 BABIĆ, I., op. cit., str. 261.

102 PEZO, V. (gl. ur.), Odrednica: Vlastoručna oporuka, op. cit., str. 1767., v. i odluku Vrhovnog suda RH, Gž-1866/56 prema CRNIĆ, J., Zakon o nasljeđivanju, Organizator, Zagreb, 1998., str. 101.

103 KREČ, M., PAVIĆ, Đ., loc. cit.

104 CRNIĆ, J., Što je donio novi Zakon o nasljeđivanju, Hrvatska pravna revija, god. 3., br. 11., Zagreb, 2003., str. 17.

105 Odluka Vrhovnog suda Republike Hrvatske, Rev-436/03-2 od 31. 3. 2004., prema: KONTREC, D., RUŽDJAK MATKO, J., SESSA, Đ., Zakon o nasljeđivanju: s komentarima, poveznicama, sudskom praksom, prilozima, primjerima i abecednim kazalom pojmova, Organizator, Zagreb, 2015., str. 43.

106 V. Odluku Vrhovnog suda RH, Rev 436/2003-2, dostupno na: Oporuka u sudskoj praksi, https://legalis.hr/blogs/entry/58-oporuka-u-sudskoj-praksi/ (25. 9. 2021.). 
Simboli poput križa, polumjeseca, Davidove zvijezde itd., ne mogu se upotrijebiti u svrhu potpisivanja sastavljene holografske oporuke. ${ }^{107}$ Osoba koja se zna samo potpisati, ne može se uzeti za pismenu osobu. ${ }^{108,}{ }^{109}$ Također, inicijali ${ }^{110}$ ne mogu biti priznati kao pravno valjani potpis. ${ }^{111}$ Isto se odnosi i na faksimil potpisa. Premda je najbolji potpis na holografskoj oporuci onaj koji se sastoji od punog imena i prezimena, isti može sadržavati samo prvo slovo imena i puno prezime, ${ }^{112}$ kao i skraćeni potpis ${ }^{113}$ koji je oporučitelj koristio u pravnom prometu. ${ }^{114}$ U svakom slučaju, važno je utvrditi izvornost potpisa koji se nalazi na oporuci te nepostojanje dvojbe o tome tko su univerzalni i/ili singularni sukcesori. Valjanim treba priznati, dakle, onaj potpis koji je oporučitelj inače koristio tijekom svog života. ${ }^{115}$ Zanimljiv primjer, u pogledu formuliranja potpisa oporučitelja, može se naći u pravu Kraljevine Belgije. U nekoliko posljednjih desetljeća, Cour de Cassation kao pravovaljan potpis holografske oporuke priznaje bilo kakav znak koji može dokazati namjeru oporučitelja da je doista htio potpisati oporuku. Ako se utvrdi da je on imao jasnu namjeru potpisati ispravu kao svoju oporuku, takav

107 BABIĆ, I., loc. cit.

108 BABIĆ, I., loc. cit.

109 'Za osobu koja je doduše završila četiri razreda osnovne škole, ali se znade - vrlo teško i nečitljivo - samo potpisati, ne može se smatrati da zna čitati i pisati...” Vrhovni sud RH, Gž-783/66. od 8. 6. 1966. prema CRNIĆ, J., op. cit., str. 102.

110 Inicijali (od. lat. initium - početak) su početna slova imena i prezimena; u starinskim rukopisima i u tipografskom radu - početna slova velikih razmjera, često ornamentirana i obojena prema KLAIĆ, B., Odrednica: Inicijali, op. cit., str. 590.

111 Kad je riječ o potpisivanju oporuke inicijalima, tu su i stajališta, koja na takvo potpisivanje gledaju afirmativno, uz dodatnu napomenu, kako formalna punovažnost oporuke nije upitna, ali materijalna punovažnost može biti, pošto potpisivanje samo inicijalima, može indicirati da volja oporučitelja nije bila ozbiljna. V. ĐURĐEVIĆ, D., loc. cit.

112 'Pravno je valjana oporuka koju je svojom rukom napisao i potpisao oporučitelj velikim tiskanim slovima

pri čemu niti okolnost što se njegov potpis na oporuci sastoji od početnog slova vlastitog imena i cijelog

prezimena nema utjecaja na njenu valjanost.” Vrhovni sud RH, Rev 1226/07-2, dostupno na: Prilozi Hrvatske javnobilježničke komore, https://www.hjk.hr/Portals/0/CasopisJB/Prilog\%20uz\%20br\%2036.pdf?ver=K-AGHRoSwepVU1Ko0ZG88Q\%3d\%3d, (26. 9. 2021.).

113 Kad se govori o potpisivanju oporuke parafom, kao skraćenim potpisom, mišljenja su podijeljena. Tvrdi se, također, da ne može biti pravno valjana oporuka koja je potpisana samo na taj način. V. GAVELLA, N., BELAJ, V., loc. cit.

114 SVORCAN, S., Komentar..., cit. u bilj. 60, str. 207.

115 BELAJ, V., op. cit., str. 11. - 12. 
potpis je validan. Validan je i ako se ne radi o njegovom uobičajenom potpisu, nego o potpisu koji je upotrijebljen samo i isključivo za tu priliku. ${ }^{116}$

\subsection{Potpis oporuke sačinjene na više listova}

Ako se holografska oporuka sastoji od više listova, oporučitelj bi trebao potpisati svaki od tih listova. Međutim, ako ne bi bili potpisani svi listovi oporuke, ista neće ostati bez pravnih učinaka. ${ }^{117}$ Naime, bit će dovoljno i ako se potpis nalazi na koncu teksta oporuke. Dakle, korisno je i uputno oporuku, sačinjenu od više listova, potpisati na svakom listu radi lakšeg utvrđivanja valjanosti i autentičnosti iste, posebice na sudu. ${ }^{118}$ Važno je da postoji jasna i nedvojbena povezanost čitave oporuke od početka do konca teksta, odnosno do potpisa. To se može postići obrojčavanjem stranica i sl. Na taj način se mogu izbjeći sporovi između nasljednika u pogledu sadržaja sastavljene oporuke. ${ }^{119}$

\subsection{Potpisivanje oporuke sačinjene u vidu deklaracije}

Ako se radi o holografskoj oporuci napisanoj u vidu deklaracije, ${ }^{120} \mathrm{u}$ pravnoj teoriji nailazi se na različita mišljenja. Jedni teoretičari smatraju da nije nužno staviti potpis ispod teksta oporuke. $U$ takvoj oporuci dovoljno je ime i prezime oporučitelja, napisano rukopisom u samom tekstu oporuke. ${ }^{121}$ Tvrdi se da svečano samoimenovanje, koje je sadržano u njezinom uvodu, pokazuje konačnu odluku volje oporučitelja. ${ }^{122}$ Drugi, pak, teoretičari smatraju da unošenje potpisa oporučitelja na početku oporuke, u vidu deklaracije, oporuku čini pravno nevaljanim poslom jer nije ispoštovan traženi zakonski oblik. Tvrde da oporučiteljev potpis ne može biti zamijenjen napisanim imenom i prezimenom u tekstu oporuke jer nema značenje potpisa sukladnog zakonu. ${ }^{123}$ Sudska praksa, također,

\footnotetext{
116 HAYTON, D. (Ed.), European Succession Laws, Jordans, Bristol, 2002., str. 56.

117 KONTREC, D., RUŽDJAK MATKO, J., SESSA, Đ., op. cit., str. 43.

118 JALŠOVEČKI, G., Nasljedno pravo - oporuka, Financije i porezi, br. 1., Zagreb, 2006., str. 191.

119 CRNIĆ, J. et al., Novo nasljednopravno uređenje, Narodne novine, Zagreb, 2003., str. 69.

120 'Ja, Petar Perić, želim rasporediti svoju imovinu..."

$121 \quad$ SVORCAN, S., Komentar ..., cit. u bilj. 60., str. 207.

122 GRUNDMANN, S., Favor Testamenti: Zu Formfreiheit und Formzwang bei privatschriftlichen Testamenten, Archiv für die civilistische Praxis, Bd. 187., H. 4.-5., Tübingen, 1987., str. 457.

123 ĐOKIĆ, D., loc. cit.
} 
ukazuje na to da na koncu napisane oporuke mora stajati potpis jer se time potvrđuje činjenica da je tekst oporuke iznad potpisa izraz stvarne oporučiteljeve volje. Podaci o oporučitelju koji su sadržani na početku teksta oporuke pisane u vidu deklaracije, bez potpisa na koncu oporuke, ukazuju samo na identitet osobe koja tek počinje pisati oporuku te ne mogu imati značaj potpisa holografske oporuke. Budući da je oporuka strogo formalni akt, ovakva oporuka ima nedostatak u obliku i nije pravovaljana. ${ }^{124}$

\section{Zaključak}

Holografska oporuka predstavlja jedan od najzastupljenijih oporučnih oblika u modernim pravima. Njene prednosti su svakako veće od nedostataka koje sadrži. Međutim, za nju se vežu i doktrinarne dvojbe, različita zakonodavna rješenja, kao i stavovi sudske prakse. Kada je riječ o potrebi pisanja datuma u oporuci, držimo da bi isti trebao biti obvezatan de lege ferenda u domaćim propisima, u kojima ne postoji obveza njegovog pisanja osim preporuke. Naime, datum je važan prilikom utvrđivanja spornih činjenica vezanih uz oporuku, za razlikovanje nacrta oporuke od posljednje volje oporučitelja, kao i za primjenu pravila da kasnija oporuka ukida djelovanje ranije, u mjeri u kojoj se njen sadržaj razlikuje od one koja je prije napisana. Premda bi potpis holografske oporuke trebao sadržavati puno ime i prezime, smatramo da bi de lege ferenda trebalo propisati uvažavanje onih potpisa koji ne stvaraju nikakvu sumnju o tome tko je autor oporuke. To implicira one potpise u kojima je sadržana oznaka odnosa s nasljednicima (npr. "vaš otac"), kao i ime, nadimak pod kojim je ostavitelj poznat u sredini u kojoj živi, skraćeni potpis kojim se koristio u pravnom prometu i sl. Također, smatramo da svatko onaj tko ne zna čitati i pisati ili ne može čitati i pisati, treba praviti javnu oporuku kako bi se prevenirale moguće zloupotrebe oporučiteljeve npr. sljepoće. Isto se odnosi i na maloljetnike koji imaju oporučnu sposobnost $\mathrm{s}$ ciljem sprečavanja, teško dokazivog, nedopuštenog utjecaja na mlađe osobe.

Što se tiče oporuke pisane stenografski, potrebno je de lege ferenda iznimno dopustiti takav način oporučivanja ako ga okolnosti konkretnog slučaja opravdavaju. Isto se odnosi na odabir neobičnog materijala ili sredstva za pisanje holografske oporuke. Po pitanju pravovaljanosti oporuke sačinjene u vidu deklaracije, smatramo da pravnu normu treba ekstenzivno tumačiti. Razlog za to je izbjegavanje pojavljivanja nevaljanih oporuka, u kojima oporučitelj najčešće nije ni razmišljao 
o tome je li pravilno postupio stavljajući svoje ime i prezime u tekst oporuke umjesto ispod teksta napisane oporuke. Kada je riječ o holografskoj oporuci napisanoj tiskanim slovima kojima se služi određeni broj osoba (posebice starije životne dobi), smatramo da ista može biti pravovaljana ako je opravda i znanje grafološke struke.

\section{HANDWRITING REQUIREMENTS FOR HOLOGRAFIC WILL}

Summary: Holografic will is recognized by the most famous civil law codifications in the world. The most important advantages of holografic will are: complete secrecy of content, ability to make a will in a simple way at minimal cost. It's disadvantages are: susceptibility to falsification, incomprehensibility of certain words or sentences occasionally, insecurity in terms of keeping it by the testator. Holografic will is like every will strictly legal business which form is one of the conditions of it's validity.

The basic condition of holografic will legal validity is requirement of hanwrinting in it's compilation and signing. The limits of handwriting requirements regarding their legal and practical significance are explored in this paper. It also analyzes the normative definition of a will, legal effects of a holografic will written by a testator with physical disabilities who used external assistance, legal effects of stenografic compilation of holografic will, question of term'handwriting' content, legal consequences of signing a will made in a form of declaration, signing a will written in several sheets, etc.

Comparative law as well as relevant case practices are consulted. Solutions de lege ferenda regarding contraversial issues and diversities in legal science point of views are proposed.

Keywords: free will, holographic will, legal validity of the will, manuscript, stenography, testator's signature, physical disabilities of the testator, will in the form of declaration. 